\title{
ARBITRASE SEBAGAI MEKANISME PENYELESAIAN SENGKETA PENANAMAN MODAL
}

(Arbitration as Investment Dispute Settlement Mechanism)

\author{
Helmi Kasim \\ Pusat Penelitian dan Pengkajian Perkara MKRI \\ Jl. Medan Merdeka Barat No. 6, Jakarta Pusat, Indonesia \\ Email: helmi_kas@mahkamahkonstitusi.go.id; helmi.kasim75@gmail.com
}

Naskah diterima: 20 Februari 2018; revisi: 5 April 2018; disetujui: 17 April 2018

\begin{abstract}
Abstrak
Arbitrase merupakan mekanisme penyelesaian sengketa penanaman modal yang banyak dipilih oleh para pihak yang bersengketa termasuk dalam hal penanaman modal asing yang dilakukan berdasarkan perjanjian bilateral penanaman modal. Tulisan ini, secara deskriptif dan eksplanatoris, akan membahas penyelesaian sengketa penanaman modal melalui arbitrase. Hal-hal yang diuraikan di dalamnya mencakup kasus yang pernah dihadapi Indonesia dalam forum arbitrase, pengakuan atas putusan arbitrase internasional dan keterlibatan pihak ketiga dalam proses arbitrase untuk kasus-kasus yang berkaitan dengan kepentingan publik. Tulisan ini menyimpulkan bahwa Indonesia perlu secara konsisten mengakui putusan arbitrase internasional berdasarkan instrumen hukum internasional yang telah diakui dalam negeri meskipun tidak sepakat terhadap substansi putusan arbitrase yang telah diambil. Tulisan ini juga merekomendasikan agar dilakukan pengaturan pihak ketiga dengan mengakomodir konsep hak gugat organisasi, gugatan perwakilan atau gugatan kelompok khusus untuk kasus-kasus arbitrase yang berkaitan dengan kepentingan umum.
\end{abstract}

Kata Kunci: penanaman modal, penyelesaian sengketa, arbitrase, pihak ketiga

\begin{abstract}
Arbitration is a mechanism of investment dispute settlement which is preffered by most disputing parties also in terms of foreign investment which is conducted based on an agreed bilateral investement treaty. This writing, using descriptive and explanatory method, attempts to discuss investment dispute settlement through arbitration which covers cases that had been faced by Indonesia in arbitration forum, recognition of international arbitration award and involvement of third parties in arbitration cases that are related to public interest. This writing concludes that Indonesia should consistently recognize international arbitration decision based on international law instruments that have been ratified even if disagreement arises on the substance of the decision. This writing also recommends the adoption of the concept of organizational standing, class action and citizen lawsuits in laws and regulations to give rights to third parties to intervene in the process or arbitration for cases which are related to public interest.
\end{abstract}

Keywords: investment, dispute settlement, arbitration 


\section{A. Pendahuluan}

Penanaman modal asing memegang peranan penting dalam peningkatan perekonomian. Penanaman modal asing membawa masuk dana dan keahlian dari luar yang akan turut memperkaya, membangun dan memperkuat kapasitas ekonomi dan pembangunan dalam negeri. Penanaman modal asing menciptakan hubungan jangka panjang terhadap perekonomian dunia. Dengan kebijakan yang benar, penanaman modal asing secara langsung dapat membawa manfaat ekonomi bagi negara penerima (host) maupun investor. Dengan kata lain, penanaman modal asing secara langsung mendorong terjadinya transfer teknologi dan keahlian antara negara yang berbeda. Negara penerima modal juga mendapatkan kesempatan untuk mempromosikan produk mereka ke seluruh dunia. ${ }^{1}$

Negara-negara didunia memilikipemahaman yang sama bahwa kegiatan penanaman modal asing penting untuk meningkatkan perekonomian mereka. Begitu pula halnya dengan Indonesia. Undang-Undang Nomor 25 Tahun 2007 tentang Penanaman Modal (UU Penanaman Modal) mengamanatkan bahwa penanaman modal harus menjadi bagian dari penyelenggaraan perekonomian nasional dan ditempatkan sebagai upaya untuk meningkatkan pertumbuhan ekonomi nasional, meningkatkan lapangan kerja, meningkatkan pembangunan ekonomi berkelanjutan, meningkatkan kapasitas dan kemampuan teknologi nasional, mendorong pembangunan ekonomi kerakyatan, serta mewujudkan kesejahteraan masyarakat dalam suatu sistem perekonomian yang berdaya saing. ${ }^{2}$

Salah satu aktor penting dalam penanaman modal adalah perusahaan-perusahaan multinasional atau MNCs (multinational corporations). Perusahaan multinasional merupakan pihak yang sangat berpengaruh karena kekuatan sumber daya finansial yang mereka miliki ditambah dengan dukungan negara asalnya yang berada di belakang mereka. Perusahaanperusahaan ini mengelola dana yang jumahnya bisa lebih besar dari anggaran sebuah negara khususnya negara-negara berkembang yang sangat membutuhkan penanaman modal. Perusahaan multinasional bahkan dianggap sanggup mempengaruhi hukum penanaman modal internasional kearah yang menguntungkan mereka. Selain kemampuan untuk mempengaruhi negara tempat mereka menanamkan modal, mereka juga sanggup mempengaruhi proses penyusunan norma hukum internasional. $^{3}$

Selain perusahaan multinasional, aktor penanaman modal lainnya adalah perusahaan milik negara (state corporations). Ini merupakan cara negara untuk masuk ke dalam bidang perdagangan yang di negara berkembang biasanya dikhususkan pada sektor-sektor yang penting untuk publik. Konsep ini banyak terjadi di negara berkembang. Teori yang berlaku di negara berkembang adalah bahwa sektor-sektor

OECD, “OECD Benchmark Definition of Foreign Direct Investment."Fourth Edition,2008, hlm. 14, http://www. oecd.org/daf/inv/investmentstatisticsandanalysis/40193734.pdf (diakses 13 Februari 2018).

2 Lihat alinea kedua penjelasan umum Undang-Undang Nomor 25 Tahun 2007 tentang Penanaman Modal. Indonesia, Undang-Undang Penanaman Modal, UU No. 25 Tahun 2007, LN No. 67, TLN No. 4724, Alinea Kedua Penjelasan Umum.

3 M. Sornarajah, The International Law on Foreign Investments, Third Edition (Cambridge: Cambridge University Press, 2010) hlm. 61-62. 
yang menguntungkan perekonomian harus dikelola oleh negara sehingga keuntungannya tidak jatuh ke tangan swasta tetapi masuk ke kas negara sehingga bisa dipergunakan untuk kepentingan rakyat. ${ }^{4}$

Kebutuhan negara-negara untuk meningkatkan perekonomian mereka dan dengan adanya globalisasi dan liberalisasi telah mempertemukan berbagai kepentingan itu dalam sebuah rezim penanaman modal yang melibatkan banyak pihak. Ada saling kebutuhan, ada penawaran dan penerimaan dari satu sama lain yang memunculkan kerjasama. Lazimnya sebuah kerjasama didasarkan atas sebuah kesepakatan. Begitu pula dalam penanaman modal. Selalu ada resiko ${ }^{5}$ di dalamnya yang bisa menimbulkan persoalan atau bahkan sengketa sehingga membutuhkan penyelesaian yang juga didasarkan pada kesepakatan.

Undang-undang Penanaman Modal telah mengatur setidaknya tiga cara penyelesaian sengketa penanaman modal yakni penyelesaian berdasarkan musyawarah mufakat, melalui arbitrase atau alternatif penyelesaian sengketa serta melalui pengadilan. Dalam hal sengketa penanaman modal asing, yang melibatkan negara dan investor asing, maka mekanisme yang ditempuh berdasarkan undang-undang adalah penyelesaian sengketa melalui arbitrase internasional yang disepakati. ${ }^{6}$ Selain berdasarkan Undang-Undang Penanaman Modal, penyelesaian sengketa melalui arbitrase juga diselesaikan berdasarkan perjanjian penanaman modal bilateral atau Bilateral Investment Treaty (BIT) yang disepakati antara Indonesia dengan negara lain.

Saat ini Indonesia menjadi pihak pada 26 BIT yang berlaku mengikat (in force). ${ }^{7}$ Pada semua BIT yang disepakati tersebut terdapat ketentuan penyelesaian sengketa melalui arbitrase. Hampir semua BIT merujuk mekanisme penyelesaian sengketa melalui arbitrase ICSID. Sebagian kecil lainnya melalui arbitrase International Chamber of Commerce (ICC) ataupun melalui arbitrase ad hoc dengan mempergunakan prosedur arbitrase United Nations Commission on International Trade Law (UNCITRAL). ${ }^{8}$ Apa yang diatur dalam Undang-Undang Penanaman Modal maupun dalam BIT menunjukkan keterbukaan Indonesia terhadap rezim hukum penanaman modal internasional yang di dalamnya memuat penyelesaian sengketa penanaman modal khususnya natara negara dan investor asing (Investor State Dispute Settlement).

Apa yang diatur dalam Undang-Undang Penanaman Modal merupakan kecenderungan umum yang terjadi dalam hukum penanaman modal di berbagai negara yang juga berkaitan

4 Ibid. hlm. 63-64. Bandingkan juga dengan konsep yang berlaku di Indonesia sebagaimana yang termaktub dalam ketentuan Pasal 33 ayat (2) UUD 1945 yang berbunyi, "Cabang-cabang produksi yang penting bagi negara dan yang menguasai hajat hidup orang banyak dikuasai oleh negara".

5 Menurut Sornarajah, beberapa resiko yang terjadi dalam penanaman modal adalah persoalan ideologi (ideological hostility), Nasionalisme (nationalism), faktor etnis (ethnicity as a factor), perubahan pola industri (changes in industry patterns), kontrak yang dibuat oleh rezim sebelumnya (contracts made by previous regime), kontrak yang merugikan (onerous contract), peraturan di bidang ekonomi (regulation of the economy), masalah hak asasi manusia dan lingkungan (human rights and environmental concerns), dan situasi hukum dan ketertiban (the law and order situation). Untuk penjelasan lebih mendalam tentang resiko ini lihat Sornarajah, Ibid. hlm. 71-79.

6 Indonesia, Undang-Undang Penanaman Modal, Ps. 32.

7 UNCTAD, "International Investment Agreements Navigator. Indonesia. Bilateral Investment Treaty," Investment Policy Hub,http://investmentpolicyhub.unctad.org/IIA/CountryBits/97, (diakses 9 Maret 2018).

$8 \quad$ Ibid. 
dengan hal-hal yang diatur dalam berbagai perjanjian internasional dalam penanaman modal. Salah satu di antaranya adalah adanya ketentuan mengenai penyelesaian sengketa. Berdasarkan data United Nations onTrade and Developemnt (UNCTAD) arbitrase internasional merupakan mekanisme penyelesaian sengketa yang paling banyak dirujuk dalam sebagain besar undang-undang penanaman modal diikuti penyelesaian sengketa melalui pengadilan kemudian alternatif penyelesaian sengketa

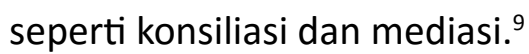

Data ini menunjukkan bahwa dalam arus penanaman modal internasional, penyelesaian sengketa melalui arbitrase merupakan mekanisme populer yang diatur dalam berbagai instrumen hukum baik hukum dalam negeri maupun perjanjian internasional. Oleh karena itu, familiaritas terhadap arbitrase merupakan sesuatu yang niscaya.Selain itu karena penanaman modal pada sektor-sektor tertentu juga berkaitan dengan kepentingan masyarakat secara luas maka sengketa yang terjadi bisa saja tidak hanya merugikan para pihak yang bersengketa namun dalam perspektif yang lebih luas dapat saja akibat dari penanaman modal yang dipersengketakan berkaitan dengan kepentingan umum sehingga masyarakat pun dalam hal ini memiliki hak utnuk tahu dan ikut bersuara terhadap substansi sengketa yang diselesaikan melalui proses arbitrase. Namun, hal ini dapat menjadi kendala sebab arbitrase merupakan mekanisme penyelesaian sengketa di mana jaminan atas kerahasiaan menjadi karakteristiknya dan untuk itu mekanisme tersebut banyak dipilih para pihak. Terkait hal tersebut, isu kepentingan umum menjadi penting untuk dibahas dan melihatnya sebagai alasan untuk mengesampingkan aspek kerahasiaan. Di ranah global isu keterlibatan pihak lain, dalam hal ini, pihak ketiga dalam proses arbitrase telah banyak dibahas khususnya untuk arbitrase yang berkaitan dengan kepentingan umum. Isu ini menjadi menarik untuk dibahas dalam konteks dalam negeri sebab sektor yang menjadi objek penanaman modal bisa saja sektor yang berkaitan dengan kepentingan umum apalagi bila dikaitkan dengan sektor-sektor yang merupakan cabang produksi yang penting bagi negara dan yang menguasai hajat hidup orang banyak serta sumber daya alam sebagaimana diatur dalam ketentuan Pasal 33 ayat (2) dan ayat (3) Undang-Undang Dasar Negara Republoik Indonesia Tahun 1945 (UUD 1945).

Berdasarkan latar belakang pemikiran tersebut, tulisan ini akan membahas dua hal yakni pertama, ulasan secara deskriptif normatif tentang arbitrase sebagai mekanisme penyelesaian sengketa khususnya di bidang penanaman modal dankedua mengkaji keterbukaan (open baar) dalam proses arbitrase terhadap sengketa yang terkait dengan kepentingan umum di mana pihak ketiga dapat melakukan intervensi pada proses arbitrase yang sedang berjalan. Hal ini penting bila dkaitkan dengan kiprah organisasi atau lembaga-lembaga non pemerintah dalam negeri yang banyak bergerak melakukan advokasi utnuk kepentingan umum di berbagai bidang yang dapat saja mendorong keterbukaan proses arbitrase baik dari segi regulasi maupun dalam pendekatan praktik. 


\section{B. Metode Penelitian}

Kajian dalam tulisan ini menggunakan metode deskriptif dan explanatoris yang menggambarkan isu penyelesaian sengketa penanaman modal melalui arbitrase. Di dalam penjelasan juga dipaparkan tentang mekanisme arbitrase yang terbuka untuk umum untuk sengketa-sengketa yang berkaitan dengan kepentingan umum. Di dalam ulasan juga diuraiakan kemungkinan berperannyaamicus curiae dalam proses arbitrase sebagai pihak yang bertindak untuk memperjuangkan kepentingan umum.

\section{Pembahasan}

\section{Arbitrase Sebagai Forum Penyelesaian Sengketa}

Penanaman modal oleh sebuah negara atau korporasi dilakukan atas dasar perjanjian.
Sebagai ajang tempat bertemunya banyak kepentingan yang berbeda, kegiatan penanaman modal tidak jarang menimbulkan sengketa. Oleh karena itu, para pihak yang melakukan kesepakatan penanaman modal selalu membekali diri dengan ketentuan tentang penyelesaian sengketa yang akan dijadikan dasar penyelesaian apabila di kemudian hari terjadi sengketa baik sengketa administratif ${ }^{10}$, sengketa hukum ${ }^{11}$ maupun sengketa teknis ${ }^{12}$.

Sengketa penanaman modal bisa terjadi antar negara ${ }^{13}$, negara dengan subyek hukum bukan negara ${ }^{14}$, subyek hukum bukan negara satu sama lain ${ }^{15}$ serta antara investor dengan masyarakat setempat ${ }^{16}$.

Penyelesaian sengketa penanaman modal dapat dilakukan melalui berbagai cara baik melalui proses ajudikasi, non-ajudikasi ${ }^{17}$ atau

10 Sengketa administartif atau biasa juga disebut sengketa tata usaha negara adalah sengketa yang timbul dalam bidang Tata Usaha Negara antara orang atau badan hukum perdata dengan Badan atau Pejabat Tata Usaha Negara, baik di pusat maupun di daerah sebagai akibat dikeluarkannya Keputusan Tata Usaha Negara. Dalam hal ini misalnya terkait dengan keputusan yang dikeluarkan oleh Badan Koordiasi Penanaman Modal.Sebastian Pompe, et. al., ed., Ikhtisar Ketentuan Penanaman Modal(Jakarta: NLRP, 2010) hlm. 454. Lihat juga ketentuan Pasal 1 angka 4 Undang-Undang Nomor 5 Tahun 1986 sebagaimana telah diubah dengan Undang-Undang Nomor 9 Tahun 2004 tentangPeradilan TataUsaha Negara.

11 Sengketa hukum biasanya timbul karena tidak diakomodasikannya kepentingan salah satu pihak atau pihak ketiga lainnya dalam suatu kegiatan penanaman modal. Ibid. hlm. 455.

12 Sengketa teknis biasanya terkait dengan hubungan kontraktual. Sengketa ini dapat terjadi karena adanya pelanggaran terhadap ketentuan kontrak kerjasama yang telah disepakati oleh kedua belah pihak yang berkerjasama, pada saat implementasi kontrak. Ibid.

13 Sengketa antar negara pada umumnya menyangkut perbedaan interpretasi dan implementasi atas perjanjian bilateral di bidang promosi dan perlindungan penanaman modal serta perjanjian lain seperti ketentuanketentuan TRIMS dari WTO Agreement, perjanjiantentangpencegahanpajakberganda dan penghindaran pajak, perjanjian kemitraan ekonomi, dll. Ibid.

14 Sengketa antar negara dengan subyek hukum bukan negara pada umumnya timbul antara host-country dengan investor asing yang melakukan penanaman modal pada host-country. Ibid.

15 Sengketa antara subyek hukum bukan negara satu sama lain adalah sengketa di antara para mitra usaha (counterparts) yang biasanya ditimbulkan oleh perbedaan interpretasi dan pelaksanaan kontrak antara investor dengan mitra lokalnya. Ibid. hlm. 456.

16 Sengketa antara investor dengan masyarakat setempat pada umumnya ditimbulkan oleh ketidakpuasan masyarakat setempat terhadap kegiatan investor pada wilayah mereka yang dapat ditimbulkan oleh berbagai faktor, antara lain: kegiatan investasi yang dapat menimbulkan dampak kerugiuan kepada msyarakat setempat; terjadinya pelanggaran HAM oleh investor; ganti rugi lahan yang sangat rendah; tidak terserapnya masyarakat pada lapangan kerja yang disediakan oleh investor, dll. Ibid.

17 Penyelesaian melalui proses non-ajudikasi yaitu negosiasi, mediasi, konsiliasi, jasa baik (good offices), komisi pencari fakta (commission of inquiry) dan board rules. Ibid. hlm. 458-460. 
gabungan antara ajudikasi dan non-ajudikasi ${ }^{18}$. Arbitrase merupakan proses penyelesaian dengan cara ajudikasi sebagaimana halnya litigasi.Menurut UNCTAD, reformasi sistem dalam negeri dan mekanisme penyelesaian sengketa penanaman modal merupakan salah satu bentuk kebijakan penanaman modal yang mempengaruhi arus investasi. UNCTAD mencotohkan salah satu bentuk kebijakan yang diambil oleh negara misalnya Bahrain membentuk dua pengadilan khusus yang masingmasing menangani masalah perdagangan dan penyelesaian sengketa penanaman modal. ${ }^{19}$ Penyusunan undang-undang arbitrase juga merupakan salah satu bentuk kebijakan peanaman modal yang memberikan kerangka hukum yang komprehensif baik untuk arbitrase domestik maupun abitrase internasional. ${ }^{20}$

Arbitrase merupakan penyelesaian sengketa melalui proses pemeriksaan dan pengambilan putusan oleh arbiter tunggal atau majelis arbiter dari lembaga arbitrase, baik oleh lembaga arbitrase yang berlingkup nasional maupun internasional, demikian pula lembaga arbitrase yang bersifat permanent maupun sementara (ad-hoc). ${ }^{21}$

Undang-Undang Nomor 30 Tahun 1999 menyebutkan arbitrase adalah cara penyelesaian suatu sengketa perdata di luar peradilan umum yang didasarkan pada perjanjian arbitrase yang dibuat secara tertulis oleh para pihak yang bersengketa. ${ }^{22}$

Arbitrase menjadi pilihan cara penyelesaian sengketa khususnya oleh pihak asing yang melakukan perjanjian karena beberapa alasan. Pertama, pada umunya pihak asing kurang mengenal system tata hukum negara lain. Kedua, adanya keraguan akan sikap objektifitas pengadilan setempat dalam memeriksa dan memutus perkara yang di dalamnya terlibat unsur asing. Ketiga, pihak asing masih ragu akan kualitas dan kemampuan pengadilan negara berkembang dalam memeriksa dan memutus perkara yang berskala internasional. Keempat, timbulnya dugaan dan kesan, penyelesaian sengketa melalui jalur formal lembaga peradilan memakan waktu yang lama. ${ }^{23}$

Para pihak dalam sebuah perjanjianjuga memilih arbitrase karena proses yang cepat, terjamin kerahasiaanya, ditangani oleh arbiter atau wasit yang ahli di bidangnya, sehingga sengketanya dapat diputuskan menurut keadilan dan kepatutan. ${ }^{24}$ Senada dengan alasan-alasan tersebut, Priyatna Abdurrasyid, menyatakan bahwa arbitrase banyak dipilih karena beberapa alasan yaitu: ${ }^{25}$

18 Penyelesaian melalui proses gabungan ajudikasi dan non-ajudikasi yaitu court-annexed mediation, mediationarbitration, dan conciliation-arbitration. Ibid. hlm. 460.

19 UNCTAD, World Investment Report 2017. op.cit., hlm. 101.

20 Ibid.

$21 \quad$ Ibid. hlm. 458.

22 Lihat ketentuan Pasal 1 angka 1 Undang-Undang Nomor 30 Tahun 1999 tentang Arbitrase dan Alternatif Penyelesaian Sengketa (Lembaran Negara Republik Indonesia Tahun 1999 Nomor 138, Tambahan Lembaran Negara Republik Indonesia Nomor 3872).

23 Erman Rajagukguk, "Keputusan Arbitrase Asing mulai dapat dilaksanakan di Indonesia”, Suara Pembaharuan, 7 Juni 1990, hlm. 11, sebagaimana dikutip M. Yahya Harahap, Arbitrase, Edisi Kedua (Jakarta: Sinar Grafika, 2006) hlm. 4.

24 Erman Suparman, Pilihan Forum Arbitrase dalam Sengketa Komersial untuk Penegakan Keadilan, cetakan pertama (Jakarta: Tatanusa, 2004) hlm. 5.

25 Priyatna Abdurrasyid, Arbitrase dan Alternatif Penyelesaian Sengketa (APS), Edisis Ke-2 Revisi (Jakarta: PT. Fikahati Aneska, 2011) hlm. 53-54. 
a. Para pihak yang bersengketa dapat memilih arbiternya sendiri dan untuk ini tentunya akan dipilih mereka yang dipercayai memiliki integritas, kejujura, keahlian, dan profesionalisme di bidangnya masing-masing dan sama sekali tidak mewakili pihak yang memilihnya. la seorang yang independen dan bukan penasehat hukumnya;

b. Proses majelis arbitrase konfidensial dan oleh karena itu dapat menjamin rahasia dan publisitas yang tidak dikehendaki;

c. Putusan arbitrase, sesuai dengan kehendak dan niat para pihak merupakan putusan final dan mengikat para pihak bagi sengketanya. Lain lagi dengan putusan pengadilan yang terbuka bagi peninjauan yang memakan waktu lama;

d. Karena putusannya final dan mengikat, tata caranya biasanya cepat, dengan biaya terukur serta jauh lebih rendah dari biayabiaya yang harus dikeluarkan dalam proses pengadilan;

e. Tata cara arbitrase lebih informal dari tata cara pengadilan dan oleh karena itu terbuka untuk memperoleh dan tersedianya tata cara penyelesaian kekeluargaan dan damai (amicable), memberi kesempatan luas untuk meneruskan hubungan komersial para pihak di kemudian hari setelah berakhirnya proses penyelesaian sengketa.
Para pihak yang memilih penyelesaian melalui arbitrase juga dapat memilih apakah akan menggunakan arbitrase ad hoc atau arbitrase terlembaga ${ }^{26}$. Baik arbitrase ad hoc maupun arbitrse terlembaga sama-sama memiliki kelebihan.

Kelebihan arbitrase ad hoc yang pertama adalah fleksibilitas. Dengan fleksibilitas ini, prosedur arbitrase ad hoc dapat ditentukan berdasarkan kesepakatan para pihak.

Kedua, kelebihan yang dimiliki arbitrase ad hoc ada pada biaya yang harus dibayar dan jangka waktu penyelesaian sengketa. Dengan memilih arbitrase ad hoc para pihak tidak perlu membayar biaya administrasi sebagaimana yang dikenakan oleh sebagian besar lembaga arbitrase dan juga waktu yang dihabiskan untuk prosedur internal seperti pemilihan arbiter, pengarsipan dokumen, dan (sebagaimana yang berlaku di ICC) prosedur penentuan kerangka acuan dan peninjauan putusan. Tiadanya prosedur internal seperti ini bisa mempersingkat waktu penyelesaian sengketa. ${ }^{27}$

Sementara kelebihan utama dari arbitrase terlembaga adalah dalam hal perancangan persetujuan arbitrase. Dengan memilih arbitrase ad hoc para pihak tidak perlu lagi merancang kesepakatan arbitrase tetapi dapat menggunakan peraturan lembaga yang dirancang oleh para professional di bidang komersial dan sudah teruji oleh waktu. ${ }^{28}$

26 Dalam hal ini Indonesia memiliki Badan Arbitrase Nasional Indonesia (BANI), dapat dikunjungi melalui laman www.bani-arb.org; Lembaga-lembaga arbitrase lainnya antara lain International Chamber of Commerce (ICC) dengan laman www.iccwbo.org; London Court of International Arbitration (LCIA), www.lcia-arbitration.com, Singapore International Arbitration Center (SIAC), www.siac.org.sg, serta International Center for the Settlement of Investment Dispute (ICSID) yang didirikan oleh Bank Dunia berdasarkan Konvensi ICSID (Convention on the Settlement of Investment Dispute between States and Nationals of Other States).

27 Gerald Aksen, "Ad Hoc Versus Institutional Arbitration," dalam Arthur Von Mehren, International Commercial Arbitration, PIL, 1997 version. Hlm. 44 - 48.

28 Ibid. 
Kedua, pemilihan arbiter. Arbitrase terlembaga lebih unggul dalam hal pemilihan arbiter. Sangat mungkin terjadi dalam arbitrase ad hoc para pihak memilih orang yang sama untuk menjadi arbiter tanpa harus menggunakan jasa arbitrase terlembaga. Namun, dalam banyak hal, pada arbitrase ad hoc, sangat sulit bagi para pihak untuk mencapai kata sepakat tentang arbiter yang dipilih karena rendahnya tingkat kepercayaan pada masing-masing pihak sehingga penunjukan arbiter independen yang dilakukan oleh sebuah lembaga yang netral dapat mempermudah proses pembentukan majelis arbitrase. Arbitrase terlembaga juga memiliki wasit administratif yang bertugas untuk memastikan bahwa semua arbiter, termasuk arbiter yang ditunjuk para pihak, benar-benar independen. Lembaga memiliki kewenangan untuk mengganti arbiter yang tidak disetujui oleh salah satu pihak. ${ }^{29}$

Ketiga, arbitrase terlembaga memiliki sekretariat dan staf profesional yang siap membantu para pihak yang bersengketa dalam proses arbitrase di antaranya melayani permintaan untuk arbitrase dan menjawab surat-surat, memproses penentuan biaya, mengingatkan para pihak tentang waktu memberikan tanggapan, memilih arbiter, dan lain-lain.

Keempat, arbitrase terlembaga telah semakin diakui oleh lembaga peradilan nasional. Secara umum pengadilan nasional menjadi lebih berterima untuk mengakui putusan di bidang perdagangan apabila ada semacam jaminan bahwa sebuah badan yang netral seperti lembaga arbitrase secara adil telah menyelesaikan kontroversi baik mengenai prosedur beracara maupun persoalan substansi yang muncul selama pelaksanaan arbitrase. ${ }^{30}$

Kelima, adanya prosedur yang dimiliki oleh lembaga arbitrase untuk meneruskan pemeriksaan tanpa kehadiran salah satu pihak apabila pihak tersebut telah dipanggil secara patut dan arbiter yakin bahwa panggilan telah diberikan dan telah diterima namun para pihak tidak hadir tanpa alasan yang sah. Dalam hal demikian, pemeriksaan arbitrase yang dilakukan dianggap telah dihadiri oleh para pihak. Prosedur seperti ini sangat penting apabila pihak yang tidak hadir adalah pemerintah suatu negara atau lembaga yang dijalankan oleh pemerintah suatu negara. Pengadilan yang akan menguatkan putusan arbitrase yang prosesnya tidak dihadiri oleh salah satu pihak tersebut (default award) juga lebih yakin apabila putusan itu dikeluarkan oleh arbitrase terlembaga. ${ }^{31}$

Dalam perjanjian penanaman modal para pihak atau setidaknya pihak pemberi modal biasanya menuntut agar perjanjian yang dibuat memuat klausula arbitrase yang tunduk pada Convention on the Settlement of Investment Dispute Between States and National of Other Statesyang tunduk pada ketentuan ICSID. Indonesia sendiri bahkan telah pernah menjadi pihak dalam sengketa penanaman modal yang diputus melalui mekanisme ICSID seperti perkara Nusa Tenggara Partnership B.V. and PT Newmont Nusa Tenggara v. Republic of Indonsia, Rafat Ali Rizvi v. Republic of Indonesia, Cemex Asia Holdings Ltd v. Republic of Indonesia

\footnotetext{
Ibid.

Ibid.

31 Ibid.
} 
dan Amco Asia Corporation and Others v. Republic of Indonesia. ${ }^{32}$ Begitupun sengketa yang diselesaikan melalui mekanisme arbitrase ad hoc seperti kasus Pertamina melawan Karaha Bodas, yang diselesaikan berdasarkan prosedur UNCITRAL, cukup menyita perhatian publik dan dunia internasional. Selain hukuman ganti rugi yang cukup tinggi sebesar USD 261 juta, putusan dalam kasus ini juga menarik perhatian publik internasional sebab putusan tersebut dibatalkan oleh Pengadilan Negeri Jakarta Pusat. ${ }^{33}$ Dalam perkembangannya putusan pembatalan ini tidak diakui negara lain. ${ }^{34}$ Berbeda dengan putusan dalam kasus Pertamina melawan Karaha Bodas, putusan arbitrase ICSID dalam kasus Rafat Ali Rizvi versus Republic Indonesia menyatakan jenis penanaman modal yang dilakukan Rafat Ali Rizvi bukan merupakan jenis penanaman modal yang masuk dalam kategori dilindungi berdasarkan penafsiran atas BIT antara Indonesia dan Inggris yang menjadi dasar penyelesaian sengketa tersebut. ${ }^{35}$ Menurut majelis arbitrase, merujuk padaketentuan Pasal 2 ayat (1)BIT tersebut, jenis penanaman modal yang dilindungi adalah penanaman modal yang telah diberi izin berdasarkan undang-undang penanaman modal yang pelaksanaannya dilakukan melalui prosedur yang ditentukan oleh Badan Koordinasi Penanaman Modal (BKPM) serta penanaman modal yang diberi izin sesuai dengan syarat-syarat yang ditentukan oleh
Indonesia untuk sektor-sektor yang terbuka bagi penanaman modal namun tidak tunduk pada prosedur yang ditetapkan oleh BKPM. Jenis penanaman modal yang dilakukan Rafat Ali Rizvi dalam kasus tersebut terdapat dalam bidang perbankan yang bukan merupakan cakupan undang-undang penanaman modal dan melalui prosedur BKPM tetapi melalui prosedur yang ditentukan oleh Bank Indonesia (BI). Dalam kasus tersebut, majelis arbitrase berpendapat bahwa Rafat Ali Rizvi tidak dapat menunjukkan bukti yang meyakinkan bahwa dirinya telah memenuhi semua persyaratan perizinan yang ditentukan BI dalam kedudukannya sebagai pemegang saham pada Bank Century. Berdasarkan pertimbangan tersebut, majelis arbitrase memutuskan, penanaman modal yang dilakukannya tidak termasuk penanaman modal yang dilindungi berdasakan ketentuan Pasal 2 ayat (1) BIT Indonesia dan Inggris. ${ }^{36}$

Merujuk pada dua kasus tersebut di atas, setidaknya ada dua hal yang dapat diketahuiyakni pembatalan putusan arbitrase internasional oleh pengadilan dalam negeri dan cakupan jenis penanaman modal yang dilindungi berdasarkan BIT. Pada poin pertama merujuk Konvensi New York 1958 yang juga sudah diratifikasi Indonesia dengan Keputusan Presiden Nomor 34 Tahun 1981 tentang Mengesahkan Convention on the Recognition and Enforcement of Foreign Arbitral Awards, putusan arbitrase internasional hanya

32 ICSID, “Concluded Cases with Details: Indonesia, diakses 9 Maret 2018, https://icsid.worldbank.org/en/Pages/ cases/ConcludedCases.aspx?status=c.

33 Helmi Kasim, "Penyelesaian Sengketa Kontrak melalui Arbitrase Internasional dalam Kasus Pertamina versus Karaha Bodas" (Skripsi SI, Universitas Islam Jakarta, 2009) , hlm. 48, 51

34 Ibid.

35 Rafat Ali Rizvi v. Republic of Indonesia. ICSID Case No. ARB/11/13, http://icsidfiles.worldbank.org/icsid/ ICSIDBLOBS/OnlineAwards/C1560/DC4512_En.pdf, diakses terakhir 9 Maret 2018.

36 Helmi Kasim, "Penyelesaian Sengketa Penanaman Modal Berdasarkan Bilateral Investement Treaty Melalui Arbitrase International Centre for the Settlement of Investment Disputes. Studi Kasus Sengketa Penanaman Modal Rafat Ali Rizvi melawan Republik Indonesia" (Tesis S2, Universitas Indonesia, 2015), hlm. 69. 
dapat dibatalkan melalui pengadilan negara yang memiliki primary jurisdiction yakni negara yang menjadi kedudukan hukum (legal seat atau juridical seat) arbitrase. Dalam kasus Pertamina versus Karaha Bodas, arbitrase yang dijalani beredudukan hukum di Swiss sehingga pengadilan Swiss lah yang berwenang untuk membatalkan putusan arbitrase tersebut. Indonesia sebagai pihak yang bersengkata dalam hal ini memiliki secondary jurisdiction yang berarti hanya memiliki kewenangan untuk menyatakan bahwa putusan tersebut tidak bisa dieksekusi di Indonesia. ${ }^{37}$ Terlepas dari ketidaksetujuan dengan substansi putusan, namun kepatuhan terhadap prosedur yang telah disepakati secara internasional perlu dipupuk untuk memberikan kepercayaan terhadap dunia global tentang iklim investasi di Indonesia sembari memperkuat kapasitas institusional dalam negeri untuk menghadapi kasuskasus serupa. Pada poin kedua, tinjauan atas ketentuan-ketentuan BIT yang disepakati antara Indonesia dengan negara lain perlu dilakukan untuk mempertegas cakupan jenis penanaman modal yang dilindungi yang dapat dimintakan pertanggungjawaban hukum melalui arbitrase bila terjadi sengketa sebab klausula tentang hal ini dapat menjadi sumber perbedaan tafsir yang rentan untuk dipersengketakan.

Dalam kasus Pertamina melawan Karaha Bodas, pengajuan upaya pembatalan putusan arbitrase oleh Pertamina kepada Pengadilan negeri Jakarta Pusat dapat dipahami sebagai upaya Pertamina untuk menghindari hukuman gantirugi.Sebab, bila putusanarbitrasedibatalkan oleh pengadilan sebuah negara yang berwenang untuk itu yakni negara yang disebut sebagai memiliki primary jurisdiction, sebagaimana yang telah dijelaskan di atas, maka putusan arbitrase tersebut tidak dapat dieksekusi di negara lain. Upaya hukum tersebut dikabulkan oleh Pengadilan Negeri Jakarta Pusat dengan membatalkan putusan arbitrase Jenewa. ${ }^{38}$ Pembatalan putusan tersebut dilakukan dengan alasan bahwa, sebagaimana yang juga didalilkan oleh Pertamina, majelis arbitrase Jenewa telah melampaui kewenangannya karena tidak menggunakan hukum Indonesia padahal dalam kontrak antara KBC dengan Pertamina disepakati bahwa hukum yang digunakan dalam penyelesaian sengketa adalah hukum Indonesia. ${ }^{39}$ Namun, putusan tersebut tidak diakui negara lain sebab pengadilan di Indonesia dianggap tidakmemiliki kewenangan untuk membatalkan putusan arbitrase yang kedudukan hukumnya (juridical seat)di negara lain.

\section{Gagasan Arbitrase Terbuka untuk Umum (Open Baar)}

Salah satu unsur yang menjadi daya tarik dari arbitrase adalah jaminan atas kerahasiaanya. Dengan kerahasiaan yang dimiliki para pihak terhindar dari publisitas yang tidak perlu. Arbitrase memang sering dilaksanakan berdasarkan aturan dan kesepakatan tentang

Helmi Kasim, “Penyelesaian...," op. cit. Hlm. 78-79.

38 Pengadilan Negeri Jakarta Pusat, Putusan Nomor 86/PDT.G/2002/PN.JKT.PST dalam kasus Pertamina melawan Karaha Bodas.

39 Hukumonline, "Sengketa Pertamina Versus Karaha Bodas. Pengadilan Batalkan Putusan Arbitrase Jenewa," http://www.hukumonline.com/berita/baca/hol6322/font-size1-colorff0000bsengketa-pertamina-vs-karahabodasbfontbrpengadilan-batalkan-putusan-arbitrase-jenewa (diakses 2 April 2018). 
kerhasiaan menyangkut substansi sengketa, identitas para pihak dan putusan yang diambil. ${ }^{41}$

Dewasa ini terdapat perkembangan baru yang mulai mempertanyakan kerahasiaan arbitrase dan alternatif penyelesaian sengketa lainnya karena kerahasiaan yang menjadi cirri khas arbitrase dan alternatif penyelesaian sengketa dianggap menjauhkan publik dari informasi yang sesungguhnya misalnya tentang kecurangan salah satu pihak. Memang tuntutan ini dimaksudkan untuk penyelesaian sengketa yang di dalamnya ada dimensi kepentingan publik. ${ }^{42}$

Dua alasan yang dijadikan dasar untuk menuntut keterbukaan adalah unconscionability danpublicpolicy. Unconscionabilitymengandung pengertian minimnya pengetahuan dan informasi yang dimiliki salah satu pihak tentang sengketa yang mereka hadapi. Tujuan pembelaan atas dasar unconscionability ini memang untuk menghindari terjadinya ketidakimbangan informasi (informational asymmetry) antara para pihak yang biasanya terjadi pada pihak yang baru pertama kali terlibat dalam penyelesaian sengketa melalui arbitrase. Persoalan seperti ini bisa terjadi misalnya dalam arbitrase yang melibatkan konsumen atau pekerja melawan perusahaan. Perusahaan yang bisa jadi pernah mengalami sengketa yang sama memiliki semua informasi yang dibutuhkan dari pengalaman mereka dalam kasus-kasus sebelumnya. Sementara, aturan kerahasiaan arbitrase menutup akses konsumen atau pekerja misalnya sebagai pihak dalam sengketa yang serupa. Kerahasiaan ini juga menutup kecurangan yang sama yang mungkin sudah dilakukan perusahaan dalam kasus-kasus sebelumnya kepada publik. ${ }^{43}$

Sementara itu, alasan public policy banyak bertumpu pada pengadilan. Tidak seperti alasan uncoscionability yang menekankan pada hubungan para pihak dan dampak perjanjian pada mereka, alasan public policy menghendaki pengadilan untuk mempertimbangkan dampak yang sama namun bukan untuk kepentingan para pihak saja tetapi untuk masyarakat pada umumnya seperti kepentingan konsumen, diskriminasi dalam pekerjaan. Pengadilan dapat melakukan ini dengan membatalkan klausula kerahasiaan dalam perjanjian arbitrase sehingga dapat membuka akses publik terhadap putusan arbitrase atau identitas para pihak. Putusan arbitrase yang di dalamnya ada unsur kepentingan umum tidak hanya mempengaruhi pihak yang bersengketa tetapi juga menjadi kepentingan pihak lain yang mungkin suatu saat akan bersengketa tentang hal yang sama, orang lain yang mungkin suatu saat menjadi korban, pembentuk peraturan perundang-undangan dan media. ${ }^{44}$

Meskipun keterbukaan dalam arbitrase tidak akan sama dengan keterbukaan yang ada pada proses litigasi namun transparansi ini perlu agar publik tahu apabila terdapat potensi bahayaatas keamanan dan kesehatan yang terdapat dalam masalah yang disengketakan yang semuanya dituangkan dalam dokumen arbitrase.

41 Laurie Kratky Doré, Public Courts Versus Private Justice: It's Time to Let Some Sun Shine In On Alternative Dispute Resolution, 2006, Chicago-Kent Law Review, www.westlaw.com.

42 Ibid.

43 Ibid.

44 Volker F. Krey Characteristic Features of German Criminal Proceedings, an Alternative to the Criminal Procedure Law of the United States dalam Luhut op.cit hlm. 163. Lihat juga "Loyola of Los Angeles International and Comparative Law Journal", August, (1994):4. 
Di bidang penanaman modal sendiri, terdapat perkembangan yang menganggap investasi dalam arbitrase masuk dalam rezim hukum publik. Meskipun sebelumnya sengketa ekonomi internasional, khususnya arbitrase internasional dianggap sebagai sengketa hukum privat, munculnya perjanjian arbitrase penanaman modal sebagai akibat dari menjamurnya perjanjian penanaman modal bilateral (Bilateral Investment Treaty) telah membawa perkembangan baru dalam proses penyelesaian sengketa ekonomi internasional. Para komentator telah sampai pada pandangan bahwa berbeda dari rezim hukum ekonomi internasional yang ada sebelumnya khususnya arbitrase komersial internasional, perjanjian arbitrase penanaman modal lebih tepat dipahami sebagai hukum publik daripada hukum privat. ${ }^{45}$

Kerahasiaan arbitrase juga dianggap hanya menguntungkan pihak yang pernah bersengketa melalui arbitrase (repeat players) karena dapat menyembunyikan informasi yang tidak menguntungkan mereka misalnya tindakan diskriminatif yang mereka lakukan yang pernah menjadi pokok perkara dalam sengketa mereka sebelumnya. Ketertutupan ini menghalangi pihak yang ingin membuktikan adanya perlakuan tidak patut yang dilakukan berulang oleh salah satu pihak. Ada juga yang berpandangan bahwa tidak teraksesnya pendapat yang menjadi pembahasan dalam proses arbitrase menghalangi perkembangan hukum khususnya pada bidang-bidang yang mempengaruhi kepentingan umum seperti hakhak warga negara dan hak konsumen. ${ }^{46}$

Unsur kepentingan publik bahkan dianggap melampaui kebebasan berkontrak para pihak yang memasukkan klausula kerahasiaan dalam perjanjian yang mereka buat. Para ahli juga mendorong pengadilan, dengan alasan kepentingan publik, misalnya dalam persoalan keamanan dan kesehatan, untuk mengabaikan kebebasan berkontrak para pihak dan membatalkan klausula kerahasiaan arbitrase. Ini dimaksudkan agar publik memperoleh akses untuk mengetahui apabila ada kecurangan atau tindakan-tindakan korpporasi yang tidak patut yang pernah terjadi sebelumnya. ${ }^{47}$

Untuk membuka akses publik terhadap dokumen arbitrase, salah satu yang didorong untuk melakukannya adalah lembaga pembentuk undang-undang meskipun ini tidak mudah sebab pembentuk undangundang harus memberikan argumentasi yang seimbang antara asas kebebasan berkontrak dan hak publik atas informasi. Pengaturan yang dilakukan legislatif dapat mengikat bukan hanya para pihak yang melakukan perjanjian arbitrase tetapi juga arbiter dan pihak ketiga yang terlibat dalam proses arbitrase. ${ }^{48}$

Kecenderungan ini terjadi dan mulai dipikirkan termasuk dalam arbitrase komersial internasional yang memang bernuansa privat. Nuansa privat ini diperoleh karena adanya proses arbitrase itu didasarkan pada otonomi para pihak dan kesepakatan untuk menyelesaikan sengketa melalui proses arbitrase. Pertanyaan

\footnotetext{
William W. Burke-White and Andreas Von Staden, Private Litigation in a Public Law Sphere: The Standard of Review in Investor-State Arbitration, The Yale Journal of Internasional Law, 2010, Vol. 35, Heinonline.

46 Amy J. Schmithz, Untangling The Privacy Paradox in Arbitration, 54. U. Kan. L. Rev. 1211 (2006). www.westlaw. com.

47 Ibid.

48 Ibid.
} 
tentang kepentingan umum mulai dimunculkan dalam proses arbitrase yang privat ini. Bagaimana kepentingan publik bisa dilindungi terkait dengan tuntutan yang diajukan ketika tuntutan itu dilakukan dalam rangka melindungi kepentingan privat? ${ }^{49}$

Semakin populernya arbitrase internasional sebagai forum penyelesaian sengketa dipandang tidak dibarengi dengan metode yang cukup untuk melindungi kepentingan publik (public interest). Untuk itu berkembang pandangan untuk mengadakan perubahan secara struktural dan prosedural (sructural and procedural changes)pada proses arbitrase, misalnya terkait kerahasiaan dan intervensi. Ada juga yang berpandangan tentang perlu adanya semacam lembaga regulator internasional (international regulatory body) untuk mengawasi pelaksanaan arbitrase komersial internasional.Meningkatnya perjanjian bilateral di bidang investasi yang memberi pilihan kepada penanam modal untuk menyelesaikan sengketa melalui arbitrase semakin menambah nuansa pentingnya pertimbangan kepentingan umum dalam proses arbitrase..$^{50}$

Pertimbangan kemudian mengarah tentang apa yang dimaksud dengan kepentingan publik dan kepentingan publik yang mana yang harus dilindungi. Ada yang memandang bahwa kepentingan publik adalah nilai-nilai dan norma yang menjadi pedoaman sekaligus sebagai tujuan yangin dicapai dalam masyarakat.

Nilai yang hidup dalam masyarakat menurut William Eskridge Jr. adalah norma-norma dan prinsip-prinsip hukum yang mendasari sikap prilaku masyarakat kita, norma yang menjadi dasar, memberikan sumbangsih dan berasal dari pembangunan moral masyarakat kita. Nilai-nilai yang hidup dalam masyarakat mengedepankan konsepsi tentang keadilan dan kebaikan bersama, bukan keinginan orang seorang atau sekelompok orang. Melalui kewenangan pengujian peraturan perundangundangan (judicial review), ${ }^{51}$ pengadilan dapat membatalkan sebuah peraturan perundangundangan yang bertentangan dengan nilainilai yang hidup dalam masyarakat (misalnya pemidanaan seseorangatas dasr ras). Meskipun jika sebuah undang-undang itu tidak dibatalkan, proses ajudikasi konstitusional yang terjadi dapat menghadirkan sebuah dialog tentang masyarakat seperti apa yang ingin kita bangun. Gagasan demikian tetap menjadi kontroversi meskipun pada saat yang bersamaan juga membawa pengaruh yang cukup besar. Perdebatan tentang peranan pengadilan untuk menyatakan apa yang menjadi nilai-nilai yang hidup dalam masyarakat dan peranannya untuk menegakkan nilai-nilai tersebut telah menimbulkan gairah intelektual yang sangat besar dalam lingkup kajian konstitusi. ${ }^{52}$

49 Dora Marta Gruner, Accounting for Public Interest in International Arbitration, 41Colum. J. Transnat'l L. 923 (2003). www.westlaw.com.

50 Ibid.

51 Dalam system ketatanegaraan kita kewenangan untuk melakukan pengujian undang-undang dilakukan oleh Mahkamah Konstitusi sedengkan pengujian peraturan perundang-undangan di bawah undang-undang dilakukan oleh Mahkamah Agung.

51 "[L]egal norms and principles that form fundamental underlying precepts for our polity--background norms that contribute to and result from the moral development of our political community. Public values appeal to conceptions of justice and the common good, not to the desires of just one person or group .... Through their power of judicial review, courts can overturn legislative enactments that violate our important public values (e.g., by penalizing 
Pertimbangan ini kemudian memunculkan tiga laternatif perubahan sebagaimana yang telah disebutkan diatas yakni dimungkinkannya intervensi, publikasi putusan-putusantertentu dandibentuknyalembagaregulatorinternasional untuk mengawasi proses arbitrase..$^{52}$

Intervensi memang sulit dalam proses arbitrase karena prosesnya yang tertutup dan belum ada aturan arbitrase yang mengatur intervensi. Oleh karena itu intervensi bisa dilakukan dengan bentuk masuknya amicus brief oleh amicus curiae ${ }^{53}$ (friends of the court) yakni pihak ketiga ${ }^{54}$ yang berkepentingan terhadap proses arbitrase. Apabila yang menjadi pihak yang berkepentingan adalah lembaga negara atau institusi pemerintah maka lembaga ini tentu akan berbicara atas nama kepentingan publik dan persoalan yang akan mereka ketengahkan adalah kepentingan publik yang melampaui kepentingan para pihak. Dengan cara seperti ini, unsur kepentingan publik bisa dipertimbangkan dalam proses arbitrase.

Keberadaan amicus curiae penting dalam arbitrase yang didasarkan atas perjanjian penanaman modal. Argumentasi ini didasarkan pada kenyataan bahwa dalam arbitrase yang melibatkan negara dan investor, investor dibolehkan untuk mengabaikan peraturan perundang-undangan dalam negeri negara tempat investasi yang dibuat secara demokratis.

persons based upon their race). Even if an enactment is not invalidated, the process of constitutional adjudication generates a useful dialogue about what kind of political community we want to be. This body of scholarship remains controversial even while it becomes increasingly influential. The academic debate about the role of courts in articulating and enforcing public values has generated great intellectual excitement in constitutional scholarship."

52 Ibid.

53 Amicus curiae adalah frasa latin yang berasal dari konsepsi Hukum Romawi dan diadopsi ke dalam sistem common law pada abad ke-17. Frasa yang dalam bahasa Inggris bermakna friend of the court ini diadakan untuk memecahkan kesulitan pihak ketiga ketika mereka ingin melakukan intervensi atas sebuah perkara di pengadilan. Oleh Dictionary of Legal Terms secara umum amicus curiae didefinisikan sebagai 'a qualified person who is not a party to the action but gives information to the court on a question of law. The function of an amicus curiae is to call attention to some important information that might escape the court's attention. An amicus curiae brief is one submitted by someone not a party to the lawsuit to give the court information needed to make a proper decision, or to urge a particular result on behalf of the public interest or of a private interest of third parties who will be indirectly affected by the results of the dispute'(seseorang yang memiliki kualifikasi yang bukan merupakan pihak yang berperkara tetapi memberikan informasi kepada pengadilan tentang suatu pertanyaan hukum. Amicus curiae dimaksudkan untuk memintakan perhatian atas beberapa informasi penting yang mungkin luput dari perhatian pengadilan. Amicus curiae brief (pendapat yang dimasukkan amicus curiae) dimasukkan oleh pihak yang bukan merupakan pihak yang berperkara terhadap perkara yang sedang diperiksa untuk memberi informasi kepada pengadilan sebagai bahan yang untuk membuat putusan yang tepat, atau untuk mendorong agar diambil putusan yang memihak kepentingan publik atau kepentingan privat pihak ketiga yang secara tidak langsung akan terpengaruh dengan putusan dalam kasus tersebut). Andre Newcombe dan Axelle Lemaire, Should Amici Curiae Participate in Investment Treaty Arbitration? 5 VJ 22 (2001).

54 Mahakamah Konstitusi memiliki mekanisme untuk mendengarkan pihak terkait dalam sidang pengujian undang-undang terhadap UUD 1945. Pihak terkait menurut ketentuan Pasal 14 Peraturan Mahkamah Konstitusi Nomor 06/PMK/2005 tentang Pedoman Beracara dalam Perkara Pengujian Undang-Undang menyatakan bahwa pihak terkait bisa pihak terkait yang berkepentingan langsung yakni pihak yang hak dan/atau kewenangannya terpengaruh oleh pokok permohonan atau pihak terkait yang berkepentingan tidak langsung. Pihak terkait yang berkepentingan tidak langsung adalah pihak yang karena kedudukan, tugas pokok dan fungsinya perlu di dengar keterangannya, atau pihak yang perlu di dengar keterangannya sebagai ad informandum, yakni pihak yang hak dan atau kewenagannya tidak secara langsung terpengaruh oleh pokok permohonan tetapi karena kepedulianya yang tinggi terhadap permohonan dimaksud. 
Tidak seperi arbitrase komersial pada umumnya, arbitrase antara negara dan investor menuntut arbiter untuk menentukan apakah peraturan yang berlaku dalam masyarakat bersesuaian dengan kewajiban investasi. Atas dasar luasnya proteksi yang diberikan dalam perjanjian investasi, adanya ketidakpastian dalam penerapannya serta pengaruh yang diimbulkan pada kewenangan pembuatan undang-undang dalam negeri menjadikan keberadaan amicus curiae dibutuhkan dalam proses arbitrase. Hal ini juga diperkuat dengan kenyataan bahwa secara teknis memang putusan arbitrase hanya mengikat para pihak namun putusan arbitrase penanaman modal sangat mungkin akan mempengaruhi peraturan perundang-undangan dalam negeri sebuah negara.Amici Curiae dapat memberikan informasi dan mengangkat isu kebijakan publik yang penting untuk memutus sengketa dengan tepat. ${ }^{55}$

Tribunal arbitrase pada awalnya menolak partisipasi amicus curiae dalam proses arbitrase dengan alasan bahwa prosedur yang diterapkan berbeda dengan pengadilan domestik atau pengadilan internasional lainnya. Dalam salah satu kasus yang diperiksa berdasarkan aturan ICSID, Aguas del Tunari SA v. The Republic of Bolivia, pada tahun 2005 yang dikenal sebagai kasus Bechtel, yang kerjasamanya dilakukan atas dasar perjanjian investasi Bilateral antara Belanda dan Inggris, tribunal arbitrase menolak kedudukan hukum masyarakat dan kelompok lingkungan yang ingin menjadi pihak dalam proses arbitrase. Tribunal berpendapat bahwa berdasarkan Konvensi ICSID dan BIT dan sifat konsesnsual arbitrase, keputusan tentang keikutsertaan amicus curiae dalam proses arbitrase diserahkan pada persetujuan para pihak yang berperkara. Karena para pihak tidak setuju maka tribunal tidak memiliki kewenangan untuk mengikutsertakan mereka dalam proses arbitrase. Putusan ini menuai kecaman dan perlawanan yang menyatakan bahwa pendekatan yang diambil tribunaltelah mengabaikan harapan masyarakat. ${ }^{56}$

Namun, dalam perkembangan terbaru, terjadi pergeseran dalam kecenderungan dalam arbitrase antara negara dan penanam modal terkait partisipasi pihak ketiga yang disinyalir sebagai akibat dari meningkatnya tekanan dan kritik publik. NAFTA misalnya telah mengadopsi ketentuan yang akan mengakomodir partisipasi pihak ketiga untuk memberikan masukan tertulis dalam proses arbitrase. Begitu pula Amerika dan Kanada yang telah memasukkan ketentuan yang membolehkan tribunal untuk memberi hak kepada pihak ketiga memberikan pendapat tertulis dalam proses arbitrase dalam ketentuan perjanjian investasi bilateral yang mereka susun. Aturan ICSID pun akhirnya diubah dengan memberikan kewenangan kepada tribunal ICSID untuk mengambil diskresi mengizinkan pihak ketiga memasukkan pendapat tertulis dalam pemeriksaan arbitrase. ${ }^{57}$

Kerahasiaan putusan arbitrase juga menjadi daya tarik arbitrase. Akan ada perdebatan antara mereka yang tetap mempertahankan kerahasiaan putusan arbitrase dan mereka yang emnginginkan transparansi. Sebagai bentuk kompromi maka dapat dilakukan pengaturan

\footnotetext{
55 Andre Newcombe and Axelle Lemaire, op.cit.

56 Eugenia Levine, Amicus Curiae in International Investment Arbitration: The Implications of an Increase in ThirdParty Participation, 29 Berkeley J. Int'l L. 200 (2011).

57 Ibid.
} 
bahwa untuk putusan yang menyangkut kepentingan umum tidak tunduk atas putusan kerahasiaan tetapi bisa dipublikasikan untuk memenuhi hak publik atas informasi.

Keberadaan sebuah lembaga regulator internasional juga penting dalam sebuah proses arbitrase internasional. Keberadaan lembaga ini perlu untuk memonitor perubahan dalam sistem arbitrase, mengkonsolidasikan publikasi putusan-putusan arbitrase, serta untuk menampung usulan-usulan yang bersifat prosedural seperti masalah intervensi dan publikasi putusan. Ada pandangan yang menyatakan bahwa keberadaan satu lembaga tunggal ini penting mengingat banyaknya lembaga arbitrase yang kesemuanya memiliki kemampuan untuk menyediakan ahli yang berkompeten untuk sengketa tertentu, kurang konsistennya hukum acara yang dimiliki oleh masing-masing lembaga arbitrase serta kemapuan masing-masing lembaga secara mandiri mengawasi arbiternya. ${ }^{58}$

Pada konteks dalam negeri, peran pihak ketiga dalam proses arbitrase ini menarik untuk dipertimbangkan dan diatur dalam peraturan perundang-undangan yang berkaitan dengan arbitrase. Konsep hak gugat organisasi, ${ }^{59}$ class action dan citizen lawsuit yang telah diakui dalam berbagai peraturan perundangundangan di Indonesia dan diakomdir oleh pengadilan dapat diadopsi untuk kasus-kasus arbitrase yang berkaitan dengan kepentingan umum. Namun, pengakuan tersebut baru sebatas untuk melakukan gugatan pada pengadilan. Pengakuan serupa sebagai pihak yang memiliki legal standing juga diatur dalam proses beracara di Mahkamah Konstitusi dalam perkara pengujian undang-undang.

Pengaturan pemberian hak untuk melakukan intervensi sebagai pihak terkait dalam proses arbitrase juga perlu dimuat dengan penegasan pada kasus-kasus arbitrase yang berkaitan dengan kepentingan umum. Hal ini juga terkait denga pemahaman bahwa rezim hukum penanaman modal termasuk ke dalam hukum publik sehingga publik pun harus diberi hak untuk mengawal proses investasi yang terjadi. Kasus-kasus yang terkait dengan pertambangan dan lingkungan hidup dapat dikategorikan sebagai berkaitan dengan kepentingan publik.

Selain diatur dalam peraturan perundangundangan dalam negeri, keterlibatan masyarakat juga perlu diatur dalam BIT yang disepakati antara Indonesia dengan negara lain. Hal ini menjadi relevan sebab terdapat klausula pembatalan putusan arbirase apabila bertentangan dengan kepentingan publik. Meskipun belum terdapat definisi yang jelas mengenai kepentingan publik tersebut, keterlibatan masyarakat, khususnya organisasi yang peduli dengan bidang-bidang penanaman modal menjadi perlu untuk diakomodasi untuk memberi ruang yang lebih luas perlindungan publik terhadap ekses penanaman modal.

8 Dora Marta Gruner, op.cit.

$59 \quad$ Hak gugat organisasi misalnya diatur dalam Pasal 92 ayat (1) Undang-Undang Nomor 32 Tahun 2009 tentang Perlindungan Lingkungan Hidup, class action yang diatur dalam belasan undang-undang di antaranya dalam pasal 92 ayat (2) Undang-Undang Nomor 21 Tahun 2013 tentang Keantariksaan, citizen lawsuit misalnya, di samping kasus-kasus lainnya, tergambar dalam gugatan yang diajukan 12 warga negara terhadap Pemerintah Provinsi DKI Jakarta dalam kasus swastanisasi air yang dimenangkan Mahkamah Agung sebagaimana tertuang dalam putusan No. 31 K/Pdt/2017. Hukum Online, "Layar Terkembang untuk Hak Gugat Organisasi, Class Action, dan Citizen Lawsuit," http://www.hukumonline.com/berita/baca/lt5a255f2b2ff59/layar-terkembang-untukhak-gugat-organisasi--class-action--dan-citizen-lawsuit (diakses 9 Maret 2018). 
Secara konstitusional pun, menurut penulis, menemukan pembenarannya dengan merujuk pada ketentuan Pasal 33 ayat (2) dan ayat (3) UUD 1945 yang memberikan mandat kepada negara untuk menguasai cabang-cabang produksi yang penting bagi negara dan menguasai hajat hidup orang banyak serta bumi dan air dan kekayaan alam yang terkandung di dalamnya. Konsep penguasaan oleh negara yang oleh Mahkamah Konstitusi disebut sebagai derivasi dari gagasan kedaulatan rakyat yang diatur dalam UUD $1945^{60}$ memberikan kewenangan kepada warga negara untuk berpartisipasi dalam pelaksanaan kebijakan publik khususnya penyelesaian sengketa penanaman modal melalui arbitrase yang menjadi pokok bahasan tulisan ini. Oleh karena itu, ukuran konsititusional ini dapat diterapkan sebagai kriteria untuk menilai apakah sebuah kasus yang sedang dipersengketakan melalui jalur arbitrase berkaitan dengan kepentingan publik atau tidak.

\section{Penutup}

Berdasarkan ulasan yang disampaikan dalam pembahasan dapat ditarik kesimpulan bahwa dalam penyelesaian sengketa penanaman modal secara internasional, arbitrase merupakan mekanisme yang banyak ditempuh para pihak. Oleh karena itu, pemahaman dan penguasaan tentang arbitrase perlu diperkuat dengan memperhatikan setiap ketentuan yang menyangkut arbitrase yang berlaku secara internasional. Kepatuhan terhadap aturan yang berlaku secara internasional yang juga diakui dalam negeri perlu selalu ditunjukkan secara konsisten untuk memberikan kepercayaan terhadap publik internasional mengenai sistem hukum dalam negeri. Posisi pengadilan dalam memeriksa keberatan terhadap putusan arbitrase asing perlu memperhatikan ketentuan tentang pengakuan terhadap putusan arbitrase internasional bahkan meskipun tidak sepakat dengan substansi putusan dengan tetap memperhatikan aspek kepentingan umum dalam persoalan yang dipersengketakan.

Selain itu, sejalan dengan perkembangan global juga perlu diatur keterlibatan pihak ketiga dalam proses arbitrase dengan mengakomodir konsep hak gugat organisasi, class action dan citizen lawsuit yang juga sudah diakui dalam berbagai peraturan perundang-undangan dan oleh pengadilan. Keterlibatan pihak ketiga atau amicus curiae penting sebagai bentuk kontrol publik khususnya pada sengketa yang berkaitan dengan kepentingan umum. Konsep ini dapat diterapkan pada kasus-kasus arbitrase yang berkaitan dengan kepentingan publik seperti sengketa di bidang pertambangan dan lingkungan hidup.

\section{Daftar Pustaka}

\section{Buku}

Abdurrasyid, Priyatna, Arbitrase dan Alternatif Penyelesaian Sengketa (APS)(Jakarta: Fikahati Aneska, 2011).

Harahap, Yahya, Arbitrase, Edisi Kedua, (Jakarta: Sinar Grafika, 2006).

Mehren, Arthur Von, International Commercial Arbitration, Cases and Material. PIL, 1997 version.

Sebastian Pompe, et. al., ed., Ikhtisar Ketentuan Penanaman Modal (Jakarta: NLRP, 2010).

Sornarajah, M.,The International Law on Foreign Investments, Third Edition (Cambridge: Cambridge University Press, 2010).

60 Lihat putusan Mahkamah Konstitusi, di antaranya, No. 001-021-022/PUU-I/2003 perihal Pengujian UndangUndang Nomor 20 Tahun 2002 tentang Ketenagalistrikan. 
Suparman, Erman, Pilihan Forum Arbitrase dalam Sengketa Komersial untuk Penegakan Keadilan, cetakan pertama(Jakarta: Tatanusa, 2004).

\section{Makalah/Artikel/Prosiding/Hasil Penelitian}

Burke-White, William W. and Andreas Von Staden, "Private Litigation in a Public Law Sphere: The Standard of Review in Investor-State Arbitration,"The Yale Journal of Internasional Law, Vol. 35, Heinonline (2010).

Doré, Laurie Kratky,“Public Courts Versus Private Justice: It's Time to Let Some Sun Shine InOn Alternative Dispute Resolution," Chicago-Kent Law Review (2006), www.westlaw.com.

Gruner,Dora Marta,"Accounting for Public Interest in International Arbitration," 41Colum. J. Transnat'I L. 923 (2003). www.westlaw.com.

Kasim, Helmi, "Penyelesaian Sengketa Kontrak melalui Arbitrase Internasional dalam Kasus Pertamina versus Karaha Bodas" (Skripsi SI, Universitas Islam Jakarta, 2009).

Levine, Eugenia,"Amicus Curiae in International Investment Arbitration: The Implications of an Increase in Third-Party Participation,"29 Berkeley J. Int'I L. 200 (2011).www.westlaw.com. Newcombe, Andre and Axelle Lemaire, "Should Amici Curiae Participate in Investment Treaty Arbitration?"5 VJ 22 (2001). www.westlaw.com. Schmithz, Amy J.,"Untangling The Privacy Paradox in Arbitration,"54. U. Kan. L. Rev. 1211 (2006). www.westlaw.com.

Trakman, Leon E, "Foreign Direct Investment: Hazard or Opportunity?" George Washington International Law Review (2009). www.westlaw. com.

\section{Internet}

BKPM, Press Release Realisasi Penanaman Modal PMDN-PMA Triwulan III dan Januari - September Tahun 2017. Jakarta, 30 Oktober2017, www. bkpm.go.id.
Hukum Online, "Layar Terkembang untuk Hak Gugat Organisasi, Class Action, dan Citizen Lawsuit," http://www.hukumonline.com/berita/baca/ It5a255f2b2ff59/layar-terkembang-untuk-hakgugat-organisasi--class-action--dan-citizenlawsuit

ICSID, "Concluded Cases with Details: Indonesia, https://icsid.worldbank.org/en/Pages/cases/ ConcludedCases.aspx?status $=c$ (diakses 9 Maret 2018).

OECD, OECD Benchmark Definition of Foreign Direct Investment. Fourth Edition, 2008,http://www. oecd.org/fr/daf/investissementinternational/ statistiquesetanalysesdelinvestissement/oecdb enchmarkdefinitionofforeigndirectinvestment4thedition.htm.

UNCTAD, World Investment Report 2017. Investment and the Digital Economy, http://unctad.org/en/ PublicationsLibrary/wir2017_en.pdf.

UNCTAD, World Investment Report 2012. Towards A New generation of Investment Policy. http://unctad.org/en/Pages/DIAE/World\%20 Investment\%20Report/WIR2012_WebFlyer. aspx.

UNCTAD, "International Investment Agreements Navigator. Indonesia. Bilateral Investment Treaty," Investment Policy Hub, http:// investmentpolicyhub.unctad.org/IIA/ CountryBits/97.

\section{Peraturan}

Undang-Undang Nomor 25 Tahun 2000 tentang Penanaman Modal

Undang-Undang Nomor 30 Tahun 1999 tentang Arbitrase dan Alternatif Penyelesaian Sengketa

\section{Putusan}

Mahkamah Konstitusi, Putusan No. 001-021-022/ PUU-I/2003 perihal Pengujian Undang-Undang Nomor 20 Tahun 2002 tentang Ketenagalistrikan.

Rafat Ali Rizvi v. Republic of Indonesia. ICSID Case No. ARB/11/13. 